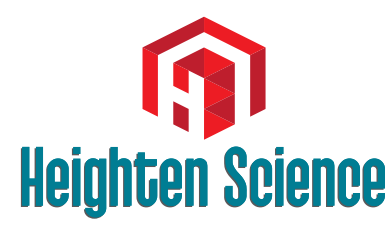

P U B L I C A T I O N S Corporation

\title{
Kummoona Chondro-Ossous Graft for Reconstruction of the Temporomandibular Joint in Children
}

\author{
Raja Kummoona* \\ Emeritus Professor of Maxillofacial Surgery, Iraqi Board for Medical Specializations, Medical \\ City, President of Iraqi Society of Maxillofacial Surgery, Iraq
}

*Address for Correspondence: Dr. Raja Kummoona, Emeritus Professor of Maxillofacial Surgery, Iraqi Board for Medical Specializations, Medical City, President of Iraqi Society of Maxillofacial Surgery, Iraq, Email: raja_kummoona@hotmail.com

Submitted: 18 September 2017

Approved: 22 September 2017

Published: 25 September 2017

Copyright: @ 2017 Kummoona R. This is an open access article distributed under the Creative Commons Attribution License, which permits unrestricted use, distribution, and reproduction in any medium, provided the original work is properly cited

Check for updates
There are a lot of controversy about the usage of graft for reconstruction of the TMJ, many researchers tried in the past different technique to be applied in the TMJ [1], for restoration of growth and all failed and some of these techniques may be used for one trial without success.

The Chondro-Ossous graft is the most valuable graft been advocated since 1986 for reconstruction of the temporomandibular joint (TMJ). There is two successful graft been used for reconstruction of the TMJ in children, the Costo-Chondral graft and Chondro-Ossous graft, Costo-Chondral graft been studied clinically by Kennett 1973 and experimentally on Mecaca Iris Monkeys 1974 by Poswillo to assess the viability of the graft [2,3], his work was a breakthrough in research and in reconstruction with restoration of growth of TMJ and this graft been widely used for reconstruction of the TMJ for few decades [4].

In 1986 the author advocates his technique of the Chondro-Ossous graft for reconstruction of TMJ instead of Costo-Chondral graft [5] and emerged as a new technique for reconstruction of the TMJ for restoration of growth, remodeling and repair of the condyle. The osseous element of graft consist from shaft of $4-5 \mathrm{~cm}$ length and $1 \mathrm{~cm}$ width with a cartilage cup, the graft harvested from iliac crest of a child between age of 4-6 years as bi cortical graft.

This graft was applied in three disease of the TMJ, ankyloses, milled hemi facial microsomia and traumatic hypoplasia of the condyle and the aim was to restore growth of the condyle, mandible and mid face, the graft has an ability to grow in multi directional fashion instead of iliac crest growth in columnar type due to change of environment of graft from weight bearing in iliac crest to masticatory process in the TMJ.

Experimental research was done on Rabbits [1,6], to demonstrate the viability of chondro-ossous graft and to demonstrate the condyle as growth center. At the end of the experiment we did postmortem studies we did observed an excellent union between the graft and ramus of the Rabbit mandible. Histological examination of the graft, showed and observed 4 zones in the first layer a thick articular layer of dense fibrocartilage due to demand of hard masticatory process of Rabbits food, the second layer showed several zones of active layers of round cells of mesenchymal stem cells which represent the proliferative layer and the third layer showed series of hypertrophic chondrocyte passed through series of changes with osteoid tissue and, the third layer represent the differentiation of mesenchymal stem cells to chondrocyte 
and osteoblast, these cellular changes represent the growth potential of the graft and the fourth layer was an osteoid bone with bony trabeculae and bone marrow spaces in between.

Previous researchers on bone, they did found a G-protein coupled receptor (CXCR4) predominantly expressed in hypertrophic chondrocyte, while its ligand Chemokine stromal cell derived factor (SDF-1) is expressed in the bone marrow adjacent to hypertrophic chondrocyte, this finding explained the endogenous growth potential of the graft to continue to grow in the condyle, mandible and mid face in children for correction of facial deformity in the affected side.

The graft has an ability to grow and did not show any sign of chondrofication or ossification of the graft on the long run, beside that the graft has the ability for remodeling, repair and restoration of growth of the TMJ as growth center.

Growth of the face and mandible controlled and directed by two theories as we believed and the first theory of primary growth in the condyle, nasal cartilage and sphenoid occipital sychandrosis as mentioned by John Hunter 1772-1773 [7], the great British scientist in his book the teeth and the second theory by Moss 1962 [8], he stated that growth of the face is a functional demand of the periosteal matrix of the facial skeleton. But the author believed that there is no single theory controlling growth of the jaws and face but both theories exist and required for growth of the face, this theory of the author based on experimental research and studies carried previously on two animal models Monkeys and Rabbits.

The objection about Costo-Chondral graft, the cartilaginous cap of the graft easily displaced from the rib due to lake of strong connection between the osseous element and the cap, perforation of the pleura might happened and an over growth of the graft might occur, the procedure required six week inter maxillary fixation(IMF), after six week the child face difficulty in opening and closing the mouth due to spasm of masticatory muscles, while in application of the Chondro-Ossous graft we do advice the child to eat within few days to enhance the graft for growth and there is no IMF or long time fixation but required active mobilization of the jaw.

Recent study [9], showed the phenomena of an over growth of costo-chondral graft was reported after five years in a child previously treated for ankyloses of TMJ and the growth pattern was un predictable and more troublesome had the patient than the lack of growth.

The graft not only used for restoration of function but also had the ability for restoration of growth, remodeling and repair of the condyle, mandible and mid face due to presence of endogenous growth potential of the graft and also based on Moss theory of functional demand of periosteal matrix of the facial skeleton.

\section{References}

1. Kummoona R. Temporomandibular reconstruction with a 2 part chrome cobalt prosthesis,chondroossous graft and silastic, clinical and experimental studies. J Craniofac Surg. 2009; 20: 2125-2135. Ref.: https://goo.gl/MWQ4Rt

2. Poswillo DE. Biological Reconstruction of mandibular condyle. $\mathrm{Br} \mathrm{J}$ Oral Maxillofac Surg. $1987 ; 25$ : 100-104. Ref.: https://goo.gl/Hfx4Gj

3. Poswillo D. Experimental reconstruction of the mandibular joint. Int J Oral Surg. 1974; 3: 400-406. Ref.: https://goo.gl/oKQyrE

4. Kennett S. Temporomandibular ankyloses the rational for grafting in the young patients. Oral Surg 1973; 31: 744-748. Ref.: https://goo.gl/5X2McG

5. Kummoona R. Chondro-Ossous iliac crest graft for one stage reconstruction of ankylosed joint in children. J Maxillofac Surg.1986; 4: 215-220. Ref.: https://goo.gl/8Mze2b 
6. Kummoona R. Functional rehabilitation of ankylosed temporomandibular joint. Oral Surg Oral Med Oral Pathol. 1978; 46: 495-505. Ref.: https://goo.gl/WUUhBU

7. Hunter J. The natural history of human teeth. $2^{\text {nd }}$ ed, London: J Johnson. 1778.

8. Moss M L. The primacy of functional matrices in orofacial growth. Dent Pract Dent Rec. 1968; 19: 65-73. Ref.: https://goo.gl/4jkMGX

9. Safavi S, Manafi A. Over growth of a costochondral graft in a case of temporomandibular joint ankyloses. J Craniofac Surg. 2007; 18: 1488-1491. Ref.: https://goo.gl/EPZaBP 